\title{
Effect of Heat Treatment on Phenolic and Flavonoid Compounds and Antioxidant Activities of Some Egyptian Sweet and Chilli Pepper
}

Shaimaa GA ${ }^{1 *}$, Mahmoud MS ${ }^{1}$, Mohamed MR $^{2}$ and Emam AA ${ }^{2}$

${ }^{1}$ Functional Food and Nutrition Department, Food Technology Research Institute, Agricultural Research Center, 12613 Giza 12613, Egypt

${ }^{2}$ Biochemistry Department, Faculty of Agriculture, Cairo University, Giza 12613, Egypt

\begin{abstract}
Raw and heat-treated (boiled) sweet and hot chilli pepper (Capsicum spp.) were evaluated for their contents of phenolic and flavonoid compounds and free radical-scavenging activity by DPPH• assay. Boiling was performed under the Egyptian household conditions. Total phenolic and total flavonoid contents were determined. Twenty six phenolic compounds and eleven flavonoid compounds were fractionated by HPLC. DPPH• assay demonstrated that both fresh and heat-treated pepper samples had a high antioxidant activity which correlated with their high contents of total phenolic and flavonoid compounds. Finally, the resulted data showed that total phenolic and total flavonoid contents were increased as the result of boiling treatment as well as the antioxidant activity.
\end{abstract}

Keywords: Pepper; Capsicum; Boiling; Antioxidant activity; Phenolic compounds; Flavonoid compounds

\section{Introduction}

Free radicals may be harmful, leading to inflammation, tissue damage and development of diseases. Free radicals are involved on the pathogenesis of at least 100 different diseases, including cancer, atherosclerosis, rheumatoid arthritis, inflammatory and cataracts [1]. Humans use several lines of defense against free radicals, including endogenous enzymes and proteins as well as dietary antioxidants. The latter are commonly found in fruits and vegetables and therefore their consumption has been associated with protection against several non-communicable diseases [1-3]. Peppers are rich in free radical scavengers, including chlorophylls, carotenoids, phenolics, ascorbic acid (AA), capsaicinoids and tocopherols [4]; however, the free radical scavenging activity of peppers has been mainly attributed to their contents of polyphenols and ascorbic acid [5].

Peppers (Capsicum spp.) belong to the Solanaceae and provide several essential nutrients. Hot peppers contain phenolics (flavonoids) [6], carotenoids [7], vitamin C, vitamin E [8] and alkaloids [9], which play important roles in human health. In other studies, antioxidant activities in peppers were measured by radical-scavenging activity $[10,11]$, inhibition of lipid peroxidation [12], and metal-chelating activity [13]. Flavonoids have been shown to act as antioxidants, and they possess anti-inflammatory [14], anti-allergic [15], anti-viral [16], and anti-bacterial activities [17].

The aim of this study was to evaluate total phenolic and total flavonoid contents of both ethanol and aqueous pepper extracts for both fresh and heat-treated sweet and hot chilli pepper samples at two ripening stages (green and red), and also determine of the antioxidant activity by DPPH• assay.

\section{Materials and Methods}

\section{Chemicals}

All the utilized chemical materials (solvents, mineral salts, etc.) were purchased from El Gomhoryia, El Allamyia, El Nasr and Middle East Pharmaceutical Chemical companies, Egypt and the solvents were purified before using. Chemicals, solvents and all standard materials which were used for fractionation and identification by HPLC, purchased from Sigma/Aldrich Chemical Company, USA.

\section{Collection of plant materials and treatment}

Fruits of hot chilli pepper (Capsium frutescens var. sina) at immature stage (green color) and mature stage (red color) and others of sweet pepper (Capsium annuum var. goduion), green and red, were collected from Vegetable Breeding Research Dept., Horticultural Research Institute, Agricultural Research Center in September until December 2012 season and were identified at the same institute.

\section{Heat treatment}

Each of the four samples was washed by using of tap water, seeds were removed and divided into two groups, the first group included the fresh peppers and the other included the pepper samples which were boiled at $100^{\circ} \mathrm{C}$ in a covered pan (containing water in an approximate ratio of $1: 1, \mathrm{w} / \mathrm{v}$ fruit to water), for $15 \mathrm{~min}$. After boiling, the boiled samples were drained using a wire mesh strainer. The weight of the boiled tissues and the volume of the boiling water were determined. The boiling water was directly used for all analysis.

\section{Preparation of extracts}

Ten $\mathrm{g}$ and $20 \mathrm{~g}$ from both fresh and boiled peppers extracted with $100 \mathrm{ml}$ ethanol $80 \%(1: 10)$ and distilled water (1:5), respectively. These extracts were left up to $24 \mathrm{~h}$ at room temperature, placed in ultrasonic (BANDELIN SONOREX SUPER RK 514H) for $30 \mathrm{~min}$ and filtered through a Whatman paper No. 1. The resultant extracts were used to determine the total phenol and flavonoid content and antioxidant activity.

\section{Determination of total phenolic content}

Total phenolic content of each sample was determined using a Folin Ciocalteu assay according to the method of Singleton and Rossi [18] with slight modification. The reaction mixture contained $1 \mathrm{ml}$ of extract and $0.5 \mathrm{ml}$ of the Folin-Ciocalteu reagent, $1 \mathrm{ml}$ sodium carbonate $7.5 \%$ and $7.5 \mathrm{ml}$ of distilled water were added, respectively. After 45 min of reaction at ambient temperature, the absorbance at 765

*Corresponding author: Shaimaa GA, Functional Food and Nutrition Department, Food Technology Research Institute, Agricultural Research Center, Giza 12613 Egypt, Tel: +201129726248; E-mail: shaimaa_amgad2013@yahoo.com

Received March 22, 2016; Accepted April 18, 2016; Published April 24, 2016

Citation: Shaimaa GA, Mahmoud MS, Mohamed MR, Emam AA (2016) Effect of Heat Treatment on Phenolic and Flavonoid Compounds and Antioxidant Activities of Some Egyptian Sweet and Chilli Pepper. Nat Prod Chem Res 4: 218. doi:10.4172/2329-6836.1000218

Copyright: (c) 2016 Shaimaa GA, et al. This is an open-access article distributed under the terms of the Creative Commons Attribution License, which permits unrestricted use, distribution, and reproduction in any medium, provided the original author and source are credited. 
Citation: Shaimaa GA, Mahmoud MS, Mohamed MR, Emam AA (2016) Effect of Heat Treatment on Phenolic and Flavonoid Compounds and Antioxidant Activities of Some Egyptian Sweet and Chilli Pepper. Nat Prod Chem Res 4: 218. doi:10.4172/2329-6836.1000218

Page 2 of 6

$\mathrm{nm}$ was measured using a UV-visible spectrophotometer (Beckman). A blue color indicated the presence of phenols. A calibration curve was calculated by using of gallic acid standard $(0.1 \mathrm{mg} / \mathrm{ml})$. The total phenolic content of samples was determined in triplicates and the results were expressed as dry weight basis (DW) as mg gallic acid equivalents (GAE), per $g$ of each sample.

\section{HPLC analysis of phenolic and aromatic compounds}

Phenolic and aromatic compounds were detected by HPLC according to the method of Goupy et al. [19] as follows: the extracts were centrifuged at $10000 \mathrm{rpm}$ (in ICE Micro-MB Centrifuge/NARP 64606 instrument) for $10 \mathrm{~min}$ and the supernatant was filtrated through a $0.2 \mu \mathrm{m}$ Millipore membrane filter, then $1-3 \mathrm{ml}$ were collected in a vial for injection into HPLC Agilent (Series 1200) equipped with auto sampler injector, solvent degasser, ultraviolet (UV) detector set at 280 $\mathrm{nm}$ and quaternary HP pump (Series 1100). The column [Agilent 5HC$\mathrm{C} 18$ (2) $250 \times 4.6 \mathrm{~mm}$ ] temperature was maintained at $35^{\circ} \mathrm{C}$. Gradient separation was carried out with methanol and acetonitrile as a mobile phase at flow rate of $1 \mathrm{ml} / \mathrm{min}$. Phenolic acid standards from sigma Co. were dissolved in a mobile phase and injected into HPLC. Retention time and peak area of the tested samples were calibrated against standard solutions of different phenolic and aromatic compounds concentration by the data analysis of HEWLLET Packed (HP) software.

\section{Determination of total flavonoid content}

Total flavonoid content was measured by $\mathrm{AlCl}_{3}$ colorimetric assay according to the method of Tacouri et al. [20]. Briefly, $500 \mu \mathrm{l}$ of extract and $2 \mathrm{ml}$ of distilled water, $150 \mu \mathrm{l}$ of $5 \%$ sodium nitrate were added. After $5 \mathrm{~min}, 150 \mu \mathrm{l}$ of $10 \% \mathrm{AlCl}_{3}$ was added. A total of 2000 $\mu \mathrm{l}$ of sodium hydroxide $(1 \mathrm{M})$ were added after $1 \mathrm{~min}$ and followed by $1200 \mu \mathrm{l}$ of distilled water. The mixture was incubated for $30 \mathrm{~min}$. The absorbance was measured at $510 \mathrm{~nm}$ against a prepared blank. A yellow color indicated the presence of flavonoids. A calibration curve was calculated using quercetin standard $(0.1 \mathrm{mg} / \mathrm{ml})$. Total flavonoid content of samples was determined in triplicates and the results were expressed on dry weight basis (DW) as mg quercetin equivalents (QE), per $g$ of each sample.

\section{HPLC analysis of flavonoid compounds}

Flavonoid fractions were also identified by HPLC according to the method of Mattila et al. [21] as follows: the extracts were centrifuged at $10000 \mathrm{rpm}$ (in ICE Micro-MB Centrifuge/NARP 64606 instrument) for $10 \mathrm{~min}$ and the supernatant was filtrated through a $0.2 \mu \mathrm{m}$ Millipore membrane filter, then 1-3 ml were collected in a vial for injection into the previous HPLC Agilent (Series 1200) and HP software were used. The ultraviolet (UV) detector was set at $330 \mathrm{~nm}$ and the other conditions were set as that previously used in the fractionation of phenolic compounds.

\section{$\mathrm{DPPH} \cdot$-scavenging activity assay}

Free radical scavenging was determined using the free radical generator $\mathrm{DPPH}^{\cdot}(2,2$ - diphenyl-1- picrylhydrazyl $)$ assay based on slight modifications [22]. One $\mathrm{ml}$ of each extract was added to $1 \mathrm{ml}$ of $0.002 \%$ methanol solution of $\mathrm{DPPH}$. The mixture was thoroughly mixed using BioCote/Stuart vortex instrument and kept in the dark for $30 \mathrm{~min}$. The absorbance, using a spectrophotometer, was measured at $517 \mathrm{~nm}$ against a blank of methanol without $\mathrm{DPPH}$.

The inhibition percent was calculated as:

[A control - A extract/A control] $\times 100$

\section{Statistical analysis}

All results were expressed as means \pm standard deviation. Statistical Analysis System (SAS) 9.1 software package was used to analysis of data and significant differences between mean values were determined by least significant difference (LSD) test at $P>0.05$.

\section{Results and Discussion}

\section{Polyphenols contents and antioxidant activities}

Total phenolic contents (TPC) of ethanolic extracts ranged from 19.21 to 28.43 and 21.81 to $37.64 \mathrm{mg} \mathrm{GAE} / \mathrm{g} \mathrm{DW}$ in fresh and boiled peppers, respectively. Boiling treatment increased the total phenolic contents. These contents were increased also with maturation and chilli peppers had a high content than sweet peppers.

The present results are in agreement with Howard et al. [23] who found that total soluble phenolics ranged from 2656 to $5788 \mathrm{mg} / \mathrm{kg}$ FW and total phenols were increased with maturation. In contrast, Ghasemnezhad et al. [24] reported that phenolic content was decreased with maturity and following ripening. Hassimotto et al. [25] also showed that phenolic contents in green and red sweet peppers were 119 and $131 \mathrm{mg} / 100 \mathrm{~g} \mathrm{FW}$, respectively. Lin and Tang [26] observed that total phenols for green, yellow and red pepper were 206.0, 191.2 and $180.3 \mathrm{mg} \mathrm{GAE} / 100 \mathrm{~g}$ FW, respectively. Isabelle et al. [27] reported that total phenolic content for Capsicum annuum var. grossum, green and red, was 0.59 and $1.70 \mathrm{mg} \mathrm{GAE} / \mathrm{g} \mathrm{FW}$, respectively, and its content in Capsicum annuum var. longum, red and green chilli, was 2.77 and $1.07 \mathrm{mg} \mathrm{GAE} / \mathrm{g}$ FW, respectively. Serrano et al. [28] found that total phenols were $142 \mathrm{mg} / 100 \mathrm{~g} \mathrm{FW}$ in sweet pepper. Park et al. [29] reported that TPC ranged from 80.53 in green pepper to 122.82 $\mathrm{mg}$ GAE/g in red pepper, with significantly higher values found in the red and orange bell pepper, and significantly lower TPC values found in the green bell pepper. Zhuang et al. [30] also reported that the phenolic contents ranged from 1078.26 $\mu \mathrm{g}$ GAE/g FW for Longline Pepper Green (LPG) to $4992.40 \mu \mathrm{g}$ GAE/g FW for Fructus Capsici Red (FCR). FCR showed significantly higher phenolic contents than others $(p<0.05)$. Phenolics were accumulated along the developmental stages of pepper fruit, so the fully colored Long-Point Pepper Red (LPPR) and Point Pepper Red (PPR) showed significantly higher phenolic contents than those of green fruits $(p<0.05)$. Tundis et al. [31] showed that in immature stage the content of phenols varied from $781.4 \mathrm{mg}$ chlorogenic acid equivalent/100g FW in Fiesta cultivar to $1207.5 \mathrm{mg}$ chlorogenic acid equivalent/100 g FW in Cayenne Golden cultivar. In mature stage the phenols content ranged from $648.6 \mathrm{mg}$ chlorogenic acid equivalent/100g FW for Acuminatum cultivar to $679.6 \mathrm{mg} / 100 \mathrm{~g}$ FW chlorogenic acid equivalent for Orange Thai cultivar. Aliakbarlu et al. [32] found that TPC in red pepper was $34 \mathrm{mg}$ GAE/g DW. Chen and Kang [33] observed that TPC of red peppers in pericarp, placenta and stalk were ranged from 43.3 to $91.9 \mathrm{mg}$ GAE/g DW. Finally, Nascimento et al. [34] revealed that total phenolic contents of Capsicum frutescens whole fruits were 4.9 and $110.6 \mathrm{mg}$ GAE/g DW in hexane and acetonitrile extracts, respectively. On the other hand, Ornelas-Paz et al. [4] found that boiling caused a sequential increase in total phenolic content in all pungent peppers from 1745.9 to 2549.7 $\mu \mathrm{g}$ GAE/g FW. Increases of phenolic content in pungent peppers by cooking ranged from minimal to large (7.4-137\%). In this regard, Turkmen et al. [35] found that several cooking methods (including boiling) caused increases (2-26\%) in the phenolic content of peppers. Boiling also increased three fold the antioxidant capacity of peppers [36]. Increments of phenolic content of vegetables by cooking have been attributed to dehydration of food matrix and an improved 
Citation: Shaimaa GA, Mahmoud MS, Mohamed MR, Emam AA (2016) Effect of Heat Treatment on Phenolic and Flavonoid Compounds and Antioxidant Activities of Some Egyptian Sweet and Chilli Pepper. Nat Prod Chem Res 4: 218. doi:10.4172/2329-6836.1000218

extractability of phenolics from the food $[23,37,38]$. Cooking is able to inactivate the polyphenol oxidase enzyme during heating, leading to the inhibition of polyphenolics degradation [39]. These studies are agreed the results in Table 1. In contrast, Ornelas-Paz et al. [40] reported that decreases in the antioxidant activity of cruciferous vegetables during aqua thermal processing were attributed to the losses of water-soluble antioxidants i.e. ascorbic acid and polyphenols [41]. Interestingly, boiling significantly increased the antiradical activity of non-pungent peppers

Total flavonoid contents ranged from 10.28 to 15.52 and 11.63 to $17.62 \mathrm{mg} \mathrm{QE} / \mathrm{g}$ DW in fresh and boiled peppers, respectively. Similar to total phenolic contents, total flavonoids increased by boiling treatments and with maturation from green to red color. Data are approved by Materska and Perucka [5] who monitored that flavonoids ranged from 16.7 to $40.7 \mathrm{mg} / \mathrm{g}$ DW. Lin and Tang [26] also observed that total flavonoids for green, yellow and red pepper were 7.8, 4.1 and $10.4 \mathrm{mg}$ QE/100 g FW, respectively. Ghasemnezhad et al. [24] reported that the changes of flavonoids such as quercetin and catachin were depended on the pepper cultivars. The Zorro cultivar showed the highest concentration of quercetin and catechin at both ripening stages. Finally, Tundis et al. [31] showed that the flavonoids content followed the same trend as for the phenols content, decreasing with maturity. In immature stage Fiesta type showed high flavonoids content $(115.7 \mathrm{mg}$ QE/100 g FW). Other cultivars showed a content ranged from 93.1 to $110.2 \mathrm{mg} \mathrm{QE} / 100 \mathrm{~g}$ FW. As a whole, in mature stage flavonoids content ranged from $34.9 \mathrm{mg} \mathrm{QE} / 100 \mathrm{~g}$ FW for Fiesta type to $61.5 \mathrm{mg}$ QE/100 g FW for Orange Thai cultivar. In contrast Perucka and Materska [42] found low flavonoid contents ranged from 81.2 to $91.0 \mathrm{mg}$ QE/100 g DW.

A method commonly used to verify the antioxidant ability consists of measuring the ability of extracts or pure molecules to scavenge $\mathrm{DPPH} \bullet$. Antioxidants are able to reduce the DPPH• from purple color to yellow color upon receiving an electron or a hydrogen radical [43]. The radical scavenging effects and antioxidant activity are also demonstrated in Table 2. All of the samples were able to reduce the stable free radical 2,2-diphenyl-1-picrylhydrazyl (DPPH) to the yellow- colored diphenylpicrylhydrazine, with inhibition values ranged from 81.10 to $91.84 \%$ and 92.20 to $93.45 \%$ in fresh and boiled peppers, respectively. In contrast, free radical scavenging activity was increased in the immature peppers (green color) than mature (red) and in chilli peppers than sweet.

Total phenolic contents of aqueous extracts ranged from 11.09 to $22.13,11.20$ to 26.14 and 56.40 to $75.40 \mathrm{mg} \mathrm{GAE} / \mathrm{g} \mathrm{DW}$ in fresh, boiled and cooking water, respectively. Similar to ethanolic extracts, boiling caused increment of TPC because of cooking is able to inactivate the polyphenol oxidase enzyme during heating, leading to the inhibition of polyphenolics degradation. TPC of boiled peppers were lower than cooking water due to reach the phenolic compounds from tissues into water during boiling treatment. As the same of ethanolic extracts, in aqueous extracts TPC increased with maturation.

Total flavonoid contents of aqueous extracts ranged from 1.13 to $1.51,2.70$ to 5.00 and 3.04 to $15.26 \mathrm{mg} \mathrm{QE} / \mathrm{g} \mathrm{DW}$ in fresh, boiled and boiling water, respectively. Boiling also caused increment of total flavonoids and boiled peppers had lower contents than cooking water as the same reason of TPC, except boiled sweet peppers.

Inhibition values of the free radical scavenging activity of aqueous pepper extracts on DPPH • ranged from 83.09 to $94.54 \%$ in fresh peppers. These values were increased in boiling water than boiled peppers due to increment of total phenolic and flavonoid contents in these extracts.

\section{Phenolic compounds fractionation}

Data of HPLC of phenolic and aromatic compounds of fresh peppers are presented in Table 3. They show that pyrogallol, 3-hydroxy tyrosol, chlorogenic, catechol, oleuropein, E-vanillic and benzoic acids were presented at higher levels than other phenolic acids. Also, ethanolic extracts had high contents of phenolic compounds compared with aqueous extracts. In contrast, ellagic acid was not found in all extracts, except aqueous SGC, GGS and ethanolic GRS extracts. The data are approved by Zhuang et al. [30] who reported that the phenolic profiles in nine fresh peppers showed that the content of gallic acid in CPG (Creasing pepper green) was the highest. The content of

\begin{tabular}{|c|c|c|c|c|c|}
\hline Component & Samples & SGC & SRC & GGS & GRS \\
\hline \multirow{2}{*}{ Total phenolic contents (mg GAE/g DW) } & Fresh & $19.21 \pm 0.41^{f}$ & $28.43 \pm 0.31^{b}$ & $20.52 \pm 0.02^{\text {ef }}$ & $24.48 \pm 2.14^{c}$ \\
\hline & Boiled & $28.68 \pm 0.88^{b}$ & $37.64 \pm 0.29^{a}$ & $21.81 \pm 0.20^{\mathrm{de}}$ & $24.61 \pm 1.92^{c}$ \\
\hline \multirow{2}{*}{ Total flavonoid contents (mg QE/g DW) } & Fresh & $13.62 \pm 0.71^{\mathrm{c}}$ & $15.55 \pm 0.21^{\mathrm{a}}$ & $10.28 \pm 0.15^{\mathrm{e}}$ & $15.52 \pm 0.37^{a}$ \\
\hline & Boiled & $14.42 \pm 0.09^{b}$ & $17.62 \pm 0.18^{a}$ & $11.63 \pm 0.45^{d}$ & $15.71 \pm 0.26^{a}$ \\
\hline \multirow{2}{*}{ DPPH'-scavenging activities (\%) } & Fresh & $91.84 \pm 0.18^{c}$ & $81.10 \pm 0.85^{h}$ & $89.52 \pm 0.06^{d}$ & $82.55 \pm 0.07^{g}$ \\
\hline & Boiled & $93.45 \pm 0.50^{b}$ & $84.80 \pm 0.42^{f}$ & $95.50 \pm 0.08^{a}$ & $92.20 \pm 0.14^{\mathrm{e}}$ \\
\hline
\end{tabular}

Each value represents the mean \pm Standard Deviation; the mean values with different letters within a specific row indicate significant differences $(P<0.05)$. $\mathrm{SGC}=$ Sina green chilli, $\mathrm{SRC}=$ Sina red chilli, GGS=Godiuon green sweet, GRS=Godiuon red sweet.

Table 1: Total phenolic and total flavonoid contents and antioxidant activities of ethanolic extracts.

\begin{tabular}{|c|c|c|c|c|c|}
\hline Component & Samples & SGC & SRC & GGS & GRS \\
\hline \multirow{3}{*}{$\begin{array}{c}\text { Total } \\
\text { phenolic contents } \\
\text { (mg GAE/g DW) }\end{array}$} & Fresh & $11.09 \pm 0.96^{h}$ & $13.96 \pm 3.07^{g}$ & $13.78 \pm 5.27^{g}$ & $22.13 \pm 0.05^{d e}$ \\
\hline & Boiled & $11.20 \pm 0.25^{\mathrm{h}}$ & $16.12 \pm 0.05^{f}$ & $20.92 \pm 0.65^{\mathrm{e}}$ & $26.14 \pm 0.78^{d}$ \\
\hline & B.W. & $68.81 \pm 1.08^{b}$ & $75.40 \pm 6.14^{a}$ & $56.40 \pm 1.57^{c}$ & $72.36 \pm 1.26^{\mathrm{ab}}$ \\
\hline \multirow{3}{*}{$\begin{array}{c}\text { Total } \\
\text { flavonoid contents } \\
\text { (mg QE/g DW) }\end{array}$} & Fresh & $1.13 \pm 0.02^{\mathrm{h}}$ & $1.34 \pm 0.09^{h}$ & $1.48 \pm 0.10^{\mathrm{h}}$ & $1.51 \pm 0.04^{h}$ \\
\hline & Boiled & $2.70 \pm 0.03^{g}$ & $4.10 \pm 0.01^{\mathrm{de}}$ & $3.59 \pm 0.10^{\text {efg }}$ & $5.00 \pm 0.19^{c}$ \\
\hline & B.W. & $11.40 \pm 0.32^{b}$ & $15.26 \pm 1.93^{a}$ & $3.04 \pm 0.16^{\mathrm{fg}}$ & $4.60 \pm 0.04^{d e}$ \\
\hline \multirow{3}{*}{$\begin{array}{l}\text { DPPH'-scavenging activities } \\
(\%)\end{array}$} & Fresh & $91.00 \pm 0.71^{d}$ & $92.05 \pm 0.21^{\mathrm{c}}$ & $83.09 \pm 0.05^{f}$ & $94.54 \pm 0.30^{\mathrm{a}}$ \\
\hline & Boiled & $86.20 \pm 0.28^{e}$ & $74.68 \pm 0.92^{i}$ & $78.30 \pm 0.57^{g}$ & $77.10 \pm 057^{\mathrm{h}}$ \\
\hline & B.W. & $93.00 \pm 0.28^{b}$ & $94.45 \pm 0.21^{a}$ & $92.71 \pm 0.05^{b c}$ & $94.43 \pm 0.40^{\mathrm{a}}$ \\
\hline
\end{tabular}

SGC=Sina green chilli, SRC=Sina red chilli, GGS=Godiuon green sweet, GRS=Godiuon red sweet, B.W.=Boiling water resulted from boiling tea

Table 2: Total phenolic, total flavonoid contents and antioxidant activities of aqueous extracts. 
Citation: Shaimaa GA, Mahmoud MS, Mohamed MR, Emam AA (2016) Effect of Heat Treatment on Phenolic and Flavonoid Compounds and Antioxidant Activities of Some Egyptian Sweet and Chilli Pepper. Nat Prod Chem Res 4: 218. doi:10.4172/2329-6836.1000218

Page 4 of 6

3,4-dihydroxybenzoic acid in FCR was higher than that in other peppers. The contents of catechin showed no significant difference $(p>0.05)$ in all peppers, except FCR. LPPR had significantly higher vanillin content than other peppers. The content of benzoic acid in LPPR was $176.76 \mu \mathrm{g} / \mathrm{g} \mathrm{FW}$, and was significantly higher than that in others peppers $(p<0.05)$. The red peppers had significantly higher salicylic acid contents than the green peppers $(p<0.05)$. The content of luteolin in the peppers was similar to that of catechin. FCR had the highest content, showing $0.84 \mu \mathrm{g} / \mathrm{g} \mathrm{FW}$, and the other peppers had no significant difference $(p>0.05)$.

HPLC of phenolic and aromatic compounds of boiled pepper extracts are presented in Table 4. The data mentioned that some extracts decreased in their contents of phenolics, some not contained and others increased in their contents.So that boiling treatment caused loss of the contents of phenolic acid fractions in some extracts. Finally, HPLC of phenolic and aromatic compounds of boiling water are also observed in Table 4. The data monitored that the phenolic fractions were decreased in all boiling water.

\section{Flavonoid fractionation}

HPLC of flavonoid compounds of both ethanolic and aqueous extracts of fresh peppers are observed in Table 5. Data show that naringin, rutin, hisperdin, rosmarinic and quercetrin were presented at higher levels than other flavonoids. Also, ethanol extracts had high contents of flavonoid profiles compared with aqueous extracts.
HPLC of flavonoid compounds of both extracts of boiled pepper samples are revealed in Table 6. Data show that naringin was increased in all extracts, except ethanol SGC and aqueous SRC extracts. Rutin was increased in all extracts, except ethanol SGC and aqueous GRS extracts. Quercetrin was increased in all extracts, except ethanol red pepper extracts. Quercetin, narenginin and keampferol were increased in all extracts, except ethanol SGC and aqueous SRC extracts. Hispertin was increased in all extracts, except ethanol chilli pepper extracts. Apeginin was decreased only in ethanol and aqueous SGC and aqueous SRC extract. Finally, 7-hydroxy flavone was decreased only in ethanol SGC, aqueous SRC and GRS extracts. In contrast, hisperdin was decreased in all extracts, except aqueous SGC and GGS extracts. Also, rosmarinic was decreased in all extracts, except aqueous SGC, ethanol and aqueous GGS extracts.

HPLC of flavonoid compounds of boiling water resulted from boiling treatment are also shown in Table 6 and investigated that these water had the lowest contents of flavonoid fractions.

\section{Conclusion}

This study demonstrated that Egyptian sweet and chilli peppers, at two ripening stages (green and red), are good sources of phenolic and flavonoid compounds. Both fresh and heat-treated peppers exhibited a good free radical scavenging activity on the DPPH• and also they contained high contents of total phenolic and total flavonoid compounds in both ethanol and aqueous extracts.

\begin{tabular}{|c|c|c|c|c|c|c|c|c|}
\hline \multirow{2}{*}{ Phenolic fractions } & \multicolumn{2}{|c|}{ SGC } & \multicolumn{2}{|c|}{ SRC } & \multicolumn{2}{|c|}{ GGS } & \multicolumn{2}{|c|}{ GRS } \\
\hline & Ethanolic & Aqueous & Ethanolic & Aqueous & Ethanolic & Aqueous & Ethanolic & Aqueous \\
\hline Gallic & 0.61 & 0.24 & 0.87 & 0.31 & 0.38 & 0.11 & 0.71 & 0.69 \\
\hline Pyrogallol & 11.66 & 11.87 & 65.33 & 43.55 & 13.98 & 6.22 & 12.16 & 35.99 \\
\hline 4-amino benzoic & 0.32 & 0.38 & 0.73 & 0.21 & 0.23 & 0.09 & 0.33 & 0.84 \\
\hline 3-hydroxy tyrosol & 9.51 & 5.58 & 18.21 & 7.87 & 3.01 & 1.01 & 9.25 & 4.01 \\
\hline Protocatchoic & 0.47 & 0.37 & 1.07 & 0.68 & 0.37 & 0.12 & 0.82 & 0.39 \\
\hline Catechin & 0.70 & 0.26 & 0.72 & 0.49 & 0.30 & 0.14 & 2.69 & 0.98 \\
\hline Chlorogenic & 13.96 & 21.51 & 29.28 & 49.28 & 12.24 & 9.86 & 30.91 & 51.13 \\
\hline Catechol & 21.75 & 5.12 & 8.98 & 6.07 & 9.05 & 2.25 & 13.40 & 8.09 \\
\hline Epicatechin & 1.03 & 1.71 & 6.88 & 5.81 & 1.60 & 0.29 & 2.06 & 1.43 \\
\hline Caffeine & 0.11 & 0.16 & 4.08 & 0.38 & 0.15 & 0.08 & 0.17 & 0.50 \\
\hline$P$-hydroxy benzoic & 5.87 & 1.95 & 11.45 & 4.79 & 1.70 & 0.49 & 6.74 & 4.35 \\
\hline Caffeic & 1.60 & 0.22 & 5.39 & 0.36 & 0.16 & 0.10 & 0.59 & 0.59 \\
\hline Vanillic & 5.10 & 0.47 & 3.60 & 7.24 & 0.63 & 0.67 & 4.61 & 2.31 \\
\hline Ferulic & 1.59 & 0.12 & 7.28 & 1.82 & 0.93 & 0.07 & ND & 0.83 \\
\hline Isoferulic & 1.43 & 0.07 & 1.15 & 0.39 & 0.32 & 0.01 & 0.58 & 0.45 \\
\hline Reverstrol & 1.56 & 0.04 & 0.75 & 0.29 & 0.13 & 0.03 & 0.69 & 0.10 \\
\hline Oleuropein & 17.53 & 0.24 & 12.72 & 2.18 & 1.49 & 0.46 & 3.89 & 5.68 \\
\hline Ellagic & ND & 0.48 & ND & ND & ND & 0.14 & 0.44 & ND \\
\hline E-vanillic & 90.49 & 1.46 & 44.57 & 8.01 & 24.61 & 1.09 & 13.51 & 6.02 \\
\hline$\alpha$-coumaric & 1.92 & 0.05 & ND & 0.08 & 0.07 & 0.01 & 0.04 & 0.06 \\
\hline Benzoic & 65.52 & 2.98 & 94.82 & 8.11 & 32.32 & 3.49 & 43.30 & 8.27 \\
\hline 3,4,5-methoxy cinnamic & 0.22 & 0.02 & 0.20 & 0.08 & 0.08 & 0.02 & 0.18 & 0.19 \\
\hline Coumarin & 0.84 & 0.10 & 1.00 & 0.37 & 0.32 & 0.18 & 0.34 & 0.13 \\
\hline Salicylic & 11.87 & 0.40 & 10.79 & 0.86 & 2.70 & 0.07 & 0.60 & 0.57 \\
\hline$P$-coumaric & 1.98 & 0.06 & 1.51 & 0.24 & 0.12 & 0.04 & 0.11 & 0.28 \\
\hline Cinnamic & 7.86 & 0.46 & 1.53 & 1.00 & 1.22 & 0.37 & 0.99 & 0.79 \\
\hline
\end{tabular}

$\mathrm{SGC}=$ Sina green chilli, $\mathrm{SRC}=$ Sina red chilli, GGS=Godiuon green sweet, GRS=Godiuon red sweet

Table 3: HPLC of phenolic and aromatic compounds of both ethanolic and aqueous extracts of fresh peppers. 
Citation: Shaimaa GA, Mahmoud MS, Mohamed MR, Emam AA (2016) Effect of Heat Treatment on Phenolic and Flavonoid Compounds and Antioxidant Activities of Some Egyptian Sweet and Chilli Pepper. Nat Prod Chem Res 4: 218. doi:10.4172/2329-6836.1000218

Page 5 of 6

\begin{tabular}{|c|c|c|c|c|c|c|c|c|c|c|c|c|}
\hline \multirow{2}{*}{$\begin{array}{l}\text { Phenolic } \\
\text { fractions }\end{array}$} & \multicolumn{3}{|c|}{ SGC } & \multicolumn{3}{|c|}{ SRC } & \multicolumn{3}{|c|}{ GGS } & \multicolumn{3}{|c|}{ GRS } \\
\hline & Ethanolic & Aqueous & B.W & Ethanolic & Aqueous & B.W. & Ethanolic & Aqueous & B.W. & Ethanolic & Aqueous & B.W \\
\hline Gallic & 0.29 & 0.49 & 0.20 & 0.34 & 0.22 & 0.05 & 0.38 & 1.08 & 0.01 & 0.31 & 1.45 & 0.14 \\
\hline Pyrogallol & 17.25 & 28.57 & 1.72 & 29.16 & 21.28 & 1.02 & 15.74 & 43.49 & 1.11 & 36.82 & 39.82 & 2.71 \\
\hline 4-amino benzoic & 0.70 & 1.38 & 0.11 & 0.15 & 0.22 & 0.01 & 0.18 & 0.61 & 0.01 & 0.51 & 0.98 & 0.21 \\
\hline $\begin{array}{c}\text { 3-hydroxy } \\
\text { tyrosol }\end{array}$ & 4.97 & 7.79 & ND & 5.18 & 4.84 & 0.18 & 1.80 & 3.42 & ND & 8.13 & 2.09 & 0.01 \\
\hline Protocatchoic & 0.73 & 5.99 & 0.28 & 0.46 & 1.44 & 0.06 & 0.23 & 2.38 & 0.04 & 1.49 & 1.46 & 0.10 \\
\hline Catechin & 0.59 & 0.67 & 0.25 & 0.37 & 0.59 & 0.06 & 0.18 & 1.40 & 0.06 & 0.42 & 0.68 & 0.17 \\
\hline Chlorogenic & 7.82 & 1.70 & 0.44 & 17.22 & 3.03 & 0.59 & 11.43 & 5.29 & 0.10 & 21.77 & 6.12 & 0.71 \\
\hline Catechol & 2.43 & 10.29 & ND & 3.64 & 3.48 & 0.34 & 1.75 & 6.77 & 0.04 & 2.41 & 3.75 & NF \\
\hline Epicatechin & 1.23 & 0.81 & 0.03 & 1.79 & 0.97 & 0.04 & 1.35 & 0.74 & 0.06 & 2.42 & 0.62 & 0.20 \\
\hline Caffeine & 0.33 & 0.70 & 0.07 & 2.27 & 0.35 & 0.06 & 0.12 & 0.15 & 0.02 & 0.19 & 0.36 & 0.07 \\
\hline $\begin{array}{l}P \text {-hydroxy } \\
\text { benzoic }\end{array}$ & 2.06 & 1.67 & 0.14 & 10.56 & 4.20 & 0.16 & 2.38 & 3.07 & 0.31 & 5.55 & 3.97 & 0.51 \\
\hline Caffeic & 0.10 & 1.19 & 0.17 & 0.65 & 1.00 & 0.06 & 0.23 & 0.07 & 0.02 & 0.49 & 0.15 & 0.10 \\
\hline Vanillic & 0.32 & 1.64 & 0.02 & 0.92 & 0.40 & 0.01 & 0.14 & 0.34 & 0.004 & 1.04 & 0.89 & 0.01 \\
\hline Ferulic & 3.30 & 0.51 & 0.07 & 0.68 & 1.27 & 0.07 & 0.05 & 0.06 & 0.01 & 0.18 & 0.27 & 0.10 \\
\hline Isoferulic & 0.12 & 0.27 & 0.02 & 0.26 & 0.22 & 0.04 & 0.04 & 0.15 & 0.01 & 0.46 & 0.30 & 0.02 \\
\hline Reverstrol & 0.25 & 0.74 & 0.02 & 0.12 & 0.19 & 0.03 & 0.04 & 0.07 & 0.01 & 0.10 & 0.32 & 0.02 \\
\hline Oleuropein & 0.59 & ND & 1.83 & 5.01 & ND & 0.97 & 0.34 & ND & ND & 2.19 & 11.70 & 0.29 \\
\hline Ellagic & ND & 7.54 & ND & ND & ND & 0.17 & ND & 7.76 & ND & ND & ND & 0.10 \\
\hline E-vanillic & 10.36 & 8.61 & 0.86 & 39.48 & 14.06 & 1.27 & 1.58 & ND & 0.02 & 3.91 & 3.92 & 0.11 \\
\hline$\alpha$-coumaric & 0.02 & ND & 0.01 & 0.14 & 0.03 & 0.01 & 0.01 & ND & 0.02 & 0.06 & 0.04 & 0.01 \\
\hline Benzoic & 57.01 & 17.94 & 0.36 & 55.51 & 4.31 & ND & 14.41 & 12.49 & 0.12 & 32.03 & 7.46 & NF \\
\hline 3,4,5-M. cinnamic & 0.02 & ND & 0.01 & 0.14 & 0.04 & 0.01 & 0.03 & 0.01 & 0.01 & 0.09 & 0.13 & 0.01 \\
\hline Coumarin & 0.05 & 0.16 & 0.04 & 0.52 & 0.09 & 0.02 & 0.04 & ND & 0.01 & 0.13 & 0.04 & 0.01 \\
\hline Salicylic & 0.11 & 0.84 & ND & 1.20 & 0.63 & 0.10 & 0.12 & 0.05 & 0.02 & 0.58 & 0.93 & 0.15 \\
\hline$P$-coumaric & 0.04 & 0.04 & 0.03 & 0.15 & 0.06 & 0.01 & 0.01 & 0.02 & ND & 0.11 & 0.03 & 0.01 \\
\hline Cinnamic & 0.40 & 0.78 & 0.12 & 1.32 & 0.30 & 0.03 & 0.15 & 0.22 & ND & 0.51 & 0.60 & 0.03 \\
\hline
\end{tabular}

SGC=Sina green chilli, SRC=Sina red chilli, GGS=Godiuon green sweet, GRS=Godiuon red sweet, B.W.=Boiling Water, ND=Not Detected.

Table 4: HPLC of phenolic and aromatic compounds of both ethanol and aqueous extracts of boiled peppers and boiling water.

\begin{tabular}{|c|c|c|c|c|c|c|c|c|}
\hline \multirow{2}{*}{ Flavonoid fractions } & \multicolumn{2}{|c|}{ SGC } & \multicolumn{2}{|c|}{ SRC } & \multicolumn{2}{|c|}{ GGS } & \multicolumn{2}{|c|}{ GRS } \\
\hline & Ethanolic & Aqueous & Ethanolic & Aqueous & Ethanolic & Aqueous & Ethanolic & Aqueous \\
\hline Naringin & 12.71 & 1.67 & 2.01 & 3.53 & 1.43 & 0.15 & 2.44 & 0.56 \\
\hline Rutin & 22.21 & 0.79 & 10.78 & 2.19 & 3.13 & 0.36 & 2.82 & 5.94 \\
\hline Hisperdin & 151.69 & 9.88 & 46.09 & 15.57 & 32.63 & 4.95 & 21.97 & 11.10 \\
\hline Rosmarinic & 11.95 & 0.40 & 2.23 & 2.55 & 1.77 & 0.63 & 2.35 & 0.98 \\
\hline Quercetrin & 36.21 & 1.73 & 51.61 & 5.07 & 17.37 & 1.50 & 25.09 & 3.43 \\
\hline Quercitin & 1.58 & 0.13 & 0.99 & 0.41 & 0.03 & 0.04 & 0.08 & 0.03 \\
\hline Narenginin & 0.47 & 0.05 & 0.13 & 0.29 & 0.03 & 0.02 & 0.05 & 0.03 \\
\hline Keampferol & 0.51 & 0.27 & 1.49 & 1.08 & 0.12 & 0.04 & 0.21 & 0.14 \\
\hline Hispertin & 4.99 & 0.18 & 1.88 & 0.52 & 0.11 & 0.05 & 0.18 & 0.04 \\
\hline Apegenin & 0.51 & 0.09 & 0.34 & 0.57 & 0.04 & 0.03 & 0.05 & 0.04 \\
\hline 7-hydroxy flavone & 1.43 & 0.19 & 0.62 & 1.35 & 0.07 & 0.06 & 0.13 & 0.19 \\
\hline
\end{tabular}

Table 5: HPLC of flavonoid compounds of both ethanolic and aqueous extracts of fresh peppers.

\begin{tabular}{|c|c|c|c|c|c|c|c|c|c|c|c|c|}
\hline \multirow[t]{2}{*}{ Flavonoid fractions } & \multicolumn{3}{|c|}{ SGC } & \multicolumn{3}{|c|}{ SRC } & \multicolumn{3}{|c|}{ GGS } & \multicolumn{3}{|c|}{ GRS } \\
\hline & Ethanolic & Aqueous & B.W. & Ethanolic & Aqueous & B.W. & Ethanolic & Aqueous & B.W. & Ethanolic & Aqueous & B.W \\
\hline Naringin & 1.62 & 0.52 & 0.06 & 2.40 & 0.46 & 0.11 & 0.91 & 0.340 & 0.010 & 3.40 & 0.32 & 0.02 \\
\hline Rutin & 0.93 & 1.34 & 0.07 & 5.73 & 2.24 & 0.71 & 0.69 & 0.700 & 0.010 & 1.05 & 2.98 & 0.02 \\
\hline Hisperdin & 7.08 & 7.98 & 0.06 & 6.13 & 5.62 & 0.05 & 7.88 & 8.230 & 0.002 & 15.92 & 7.82 & 0.04 \\
\hline Rosmarinic & 2.26 & 4.65 & 0.5 & 1.88 & 1.01 & 0.31 & 0.86 & 0.150 & ND & 3.09 & 0.40 & 0.06 \\
\hline Quercetrin & 40.99 & 9.74 & ND & 36.26 & 2.36 & 0.17 & 9.73 & 7.910 & 0.002 & 21.02 & 4.41 & 0.03 \\
\hline Quercitin & 0.01 & 0.13 & 0.01 & 1.06 & 0.13 & 0.10 & 0.08 & 0.010 & 0.006 & 0.07 & 0.13 & 0.01 \\
\hline Narenginin & 0.01 & 0.01 & 0.01 & 0.41 & 0.05 & 0.05 & 0.14 & 0.004 & 0.001 & 0.17 & 0.01 & 0.01 \\
\hline Keampferol & 0.06 & 0.06 & 0.03 & 0.67 & 0.06 & ND & 0.13 & 0.010 & 0.012 & 0.09 & 0.03 & ND \\
\hline Hispertin & 0.12 & 0.15 & 0.04 & 1.21 & 0.14 & 0.10 & 0.09 & 0.030 & 0.001 & 0.18 & 0.02 & 0.01 \\
\hline Apegenin & 0.04 & 0.07 & 0.01 & 0.38 & 0.02 & 0.01 & 0.16 & 0.010 & 0.006 & 0.07 & 0.03 & 0.01 \\
\hline 7-hydroxy flavone & 0.45 & 0.04 & 0.02 & 1.62 & 0.04 & 0.02 & 0.08 & 0.140 & 0.020 & 0.26 & 0.05 & 0.02 \\
\hline
\end{tabular}

Table 6: HPLC of flavonoid compounds of ethanolic and aqueous extracts of boiled peppers and boiling water. 
Citation: Shaimaa GA, Mahmoud MS, Mohamed MR, Emam AA (2016) Effect of Heat Treatment on Phenolic and Flavonoid Compounds and Antioxidant Activities of Some Egyptian Sweet and Chilli Pepper. Nat Prod Chem Res 4: 218. doi:10.4172/2329-6836.1000218

\section{References}

1. Yahia EM, Ornelas-Paz J De J (2010) Chemistry, stability and biological actions of carotenoids. In LA De la Rosa, Alvarez-Parrilla E, González-Aguilar GA (eds.), Fruit and Vegetable Phytochemicals: Chemistry, Nutritional Value and Stability, lowa: Blackwell Publishing: 177-222.

2. Davey MW, Van Montagu M, Inzé D, Sanmartin M, Kanellis A, et al. (2000) Plant L-ascorbic acid: Chemistry, function, metabolism, bioavailability and effects of processing. J Sci Food Agric 80: 825-860.

3. Harrison FE, May JM (2009) Vitamin C function in the brain: vital role of the ascorbate transporter SVCT2. Free Radic Biol Med 46: 719-730.

4. Ornelas-Paz J, Martínez-Burrola MJ, Ruiz-Cruz S, Santana-Rodríguez V Ibarra-Junquera V, et al. (2010) Effect of cooking on the capsaicinoids and phenolics contents of Mexican peppers. Food Chem 119: 1619-1625.

5. Materska M, Perucka I (2005) Antioxidant activity of the main phenolic compounds isolated from hot pepper fruit (Capsicum annuum L). J Agric Food Chem 53: 1750-1756.

6. Bae H, Jayaprakasha GK Jifon J, Patil BS (2012) Variation of antioxidant activity and the levels of bioactive compounds in lipophilic and hydrophilic extracts from hot pepper (Capsicum spp.) cultivars. Food Chem 134: 19121918.

7. Ha SH, Kim JB, Park JS, Lee SW Cho KJ (2007) A comparison of the carotenoid accumulation in Capsicum varieties that show different ripening colours: deletion of the capsanthin-capsorubin synthase gene is not a prerequisite for the formation of a yellow pepper. J Exp Bot 58: 3135-3144.

8. García-Closas R, Berenguer A, José Tormo M, José Sánchez M, Quirós JR, et al. (2004) Dietary sources of vitamin C, vitamin E and specific carotenoids in Spain. Br J Nutr 91: 1005-1011.

9. Srinivas Ch, Sai Pavan Kumar ChN, China Raju B, Jayathirtha Rao V, Naidu VG, et al. (2009) First stereoselective total synthesis and anticancer activity of new amide alkaloids of roots of pepper. Bioorg Med Chem Lett 19: 5915-5918.

10. Conforti F, Statti AG, Menichini F (2007) Chemical and biological variability of hot pepper fruits (Capsicum annuum var. acuminatum L.) in relation to maturity stage. Food Chem 102: 1096-1104.

11. Oboh G, Ademiluyi AO, Faloye YM (2011) Effect of combination on the antioxidant and inhibitory properties of tropical pepper varieties agains a-amylase and a-glucosidase activities in vitro. J Med Food 14: 1152-1158.

12. Menichini F, Tundis R, Bonesi M, Loizzo RM, Conforti F, et al. (2009) The influence of fruit ripening on the phytochemical content and biological activity of Capsicum chinense Jacq. CV Habanero. Food Chem 114: 553-560.

13. Ciz M, Cizova H, Denev P, Kratchanova M, Slavov A, et al. (2010) Different methods for control and comparison of the antioxidant properties of vegetables. Food Cont 21: 518-523.

14. Loke WM, Proudfoot JM, Stewart S, McKinley AJ, Needs PW, et al. (2008) Metabolic transformation has a profound effect on anti-inflammatory activity of flavonoids such as quercetin: Lack of association between antioxidant and lipoxygenase inhibitory activity. Biochem Pharmacolo 75: 1045-1053.

15. Seelinger G, Merfort I, Wölfle U, Schempp CM (2008) Anti-carcinogenic effects of the flavonoid luteolin. Molecules 13: 2628-2651.

16. Liu RH (2003) Health benefits of fruit and vegetables are from additive and synergistic combinations of phytochemicals. Am J Clin Nutr 78: 517S-520S.

17. Hong $H$, Landauer MR, Foriska MA, Ledney GD (2006) Antibacterial activity of the soy isoflavone genistein. J Basic Microbiol 46: 329-335.

18. Singleton VL, Rossi JAJ (1965) Colorimetry of total phenolics with phosphomolybdic-phosphotungstic acid reagents. Am J Enol Viticult 16: 144158.

19. Goupy P, Hugues M, Biovin P, Amiot MJ (1999) Antioxidant composition and activity of barely (Hordeum vulgare) and malt extracts and of isolated phenolic compounds. J Sci Food Agric 79: 1625-1634

20. Tacouri DD, Ramful-Baboolall D, Puchooa D (2013) In vitro bioactivity and phytochemical screening of selected spices used in Mauritian foods. Asian Pacific J Tropical Disease 3: 253-261.

21. Mattila P, Astola J, Kumpulainen J (2000) Determination of flavonoids in plan material by HPLC with diode-array and electro-array detections. J Agric Food Chem 48: 5834-5841.
22. Blois MS (1958) Antioxidant determinations by the use of a stable free radical. Nature 181: 1199-1200.

23. Howard LR, Talcott ST, Brenes CH, Villalon B (2000) Changes in phytochemical and antioxidant activity of selected pepper cultivars (Capsicum species) as influenced by maturity. J Agric Food Chem 48: 1713-1720.

24. Ghasemnezhad M, Sherafati M, Payvast GA (2011) Variation in phenolic compounds, ascorbic acid and antioxidant activity of five coloured bell pepper (Capsicum annuum) fruits at two different harvest times. J Fun Foods 3: 44-49.

25. Hassimotto NM, Genovese MI, Lajolo FM (2005) Antioxidant activity of dietary fruits, vegetables, and commercial frozen fruit pulps. J Agric Food Chem 53 2928-2935.

26. Lin YJ, Tang YC (2007) Determination of total phenolic and flavonoid contents in selected fruits and vegetables, as well as their stimulatory effects on mouse splenocyte proliferation. Food Chem 101: 140-147.

27. Isabelle M, Lee LB, Lim TM, Koh W, Huang D, et al. (2010) Antioxidant activity and profiles of common vegetables in Singapore. Food Chem 120: 993-1003.

28. Serrano M, Zapata JP, Castillo S, Guillén F, Martínez-Romero D, et al. (2010) Antioxidant and nutritive constituents during non-pungent pepper development and ripening are enhanced by nitrophenolate treatments. Food Chem 118: 497 503.

29. Park J, Jeon G, Kim J, Park E (2012) Antioxidant activity and antiproliferative action of methanol extracts of 4 different colored bell peppers (Capsicum annuum L.). Food Sci Biotechnol 21: 543-550.

30. Zhuang Y, Chen L, Sun L, Cao J (2012) Bioactive characteristics and antioxidant activities of nine peppers. J Functional Foods 4: 331-338.

31. Tundis R, Menichini F, Bonesi M, Conforti F, Statti G, et al. (2013) Antioxidan and hypoglycaemic activities and their relationship to phytochemicals in Capsicum annuum cultivars during fruit development. Food Sci Technol 53 : 370-377.

32. Aliakbarlu J, Mohammad S, Khalili S (2014) A study on antioxidant potency and antibacterial activity of water extracts of some spices widely consumed in Iranian diet. J Food Biochem 38: 159-166.

33. Chen L, Kang Y (2014) In vitro inhibitory potential against key enzymes relevant for hyperglycemia and hypertension of red pepper (Capsicum annuum L.) including pericarp, placenta and stalk. J Food Biochem 38: 300-306.

34. Nascimento LAP, Nascimento CEST, Ramos SMN, Silva RG, Gomes EGJ, et al. (2014) Quantification, antioxidant and antimicrobial activity of phenolics isolated from different extracts of Capsicum frutescens (pimenta malagueta). Molecules 19: 5434-5447.

35. Turkmen N, Sari F, Velioglu YS (2005) The effect of cooking methods on total phenolics and antioxidant activity of selected green vegetables. Food Chem 93: 713-718.

36. Shobana S, Naidu KA (2000) Antioxidant activity of selected Indian spices. Prostaglandins Leukot Essent Fatty Acids 62: 107-110.

37. Huffman VL, Schadle ER, Villalon B, Burns EE (1978) Volatile components and pungency in fresh and processed jalapeno peppers. J Food Sci 43: 1809-1811.

38. Schweiggert U, Schieber A, Carle R (2006) Effects of blanching and storage on capsaicinoid stability and peroxidase activity of hot chili peppers (Capsicum frutescens L.). Innovative Food Sci Emerging Technolo 7: 217-224.

39. Chuah MA, Lee Y, Yamaguchi T, Takamura H, Yin L, et al. (2008) Effect of cooking on the antioxidant properties of coloured peppers. Food Chem 111: 20-28.

40. Ornelas-Paz J, Cira-Chávez AL, Gardea-Béjar AA Guevara-Arauza CJ, Sepúlveda RD, et al. (2013) Effect of heat treatment on the content of some bioactive compounds and free radical-scavenging activity in pungent and nonpungent peppers. Food Res Intl 50: 519-525.

41. Sikora E, Cieslik E, Leszczynska T, Filipiak-Florkiewicz F, Pisulewski PM (2008) The antioxidant activity of selected cruciferous vegetables subjected to aquathermal processing. Food Chem 107: 55-59.

42. Perucka I, Materska M (2003) Antioxidant activity and content of capsaicinoids isolated from paprika fruits. Polish J Food Nutri Sci 12: 15-18.

43. Bamoniri A, Ebrahimabadi AH, Mazoochi A, Behpour M, Kashi FJ, et al. (2010) Antioxidant and antimicrobial activity evaluation and essential oil analysis of Semenovia. Food Chem 122: 553-558. 